\title{
Comparison of precipitation trends in Libya and Slovakia
}

\author{
M. Zeleňáková ${ }^{1}$, P. Purcz ${ }^{2}$, I. Gargar ${ }^{1}$ \& H. Hlavatá ${ }^{3}$ \\ ${ }^{1}$ Institute of Environmental Engineering, \\ Technical University of Košice, Slovakia \\ ${ }^{2}$ Institute of Construction Technology and Management, \\ Technical University of Košice, Slovakia \\ ${ }^{3}$ Slovak Hydrometeorological Institute, Slovakia
}

\begin{abstract}
The study of hydrological risk assessment is performed with the goal to reduce impacts of droughts and floods. Drought is the most complex but least understood of all natural hazards. It is broadly defined as "severe water shortage”. Floods cause huge but mainly material damages. Mentioned natural hazards cause loss of life, human and animal suffering and damage to economy and environment. The present study area is prone to extreme climate events such as drought and flood. The objective of this study was to investigate precipitation trends in the chosen climatic stations in Libya and Slovakia. Annual and monthly precipitation trends were detected by the Mann-Kendall statistical test. Significant negative trends of annual precipitation were found in four out of seventeen analyzed rainfall gauging stations in Libya. Significant positive trends of annual precipitation were found in six out of twenty analyzed rainfall gauging stations in Slovakia. November and August were observed to have decreasing trends in Libya and March in Slovakia. All other months displayed increasing trends in precipitation. The results show a trend towards drier conditions in Libya and an increase of moisture in Slovakia.
\end{abstract}

Keywords: precipitation, trend, Mann-Kendall statistical test, drought, flood.

\section{Introduction}

The Intergovernmental Panel on Climate Change [1] provides a comprehensive review of the potential impacts on climate. Climatic change is considered likely 
to increase runoff in the higher latitude regions because of increased precipitation on the other hand flood frequencies are expected to change also in some locations and the severity of drought events could increase as a result of those changes in both precipitation and evaporation. In all these considerations 'the issue' then becomes the effect of global warming and its impacts on the environment and water resources in particular.

Observations show that changes are occurring in the amount, intensity, frequency and type of precipitation. These aspects of precipitation generally exhibit large natural variability, and El Niño and changes in atmospheric circulation patterns such as the North Atlantic Oscillation have a substantial influence. Pronounced long-term trends from 1900 to 2005 have been observed in precipitation amount in some places: significantly wetter in eastern North and South America, northern Europe and northern and central Asia, but drier in the Sahel, southern Africa, the Mediterranean and southern Asia. More precipitation now falls as rain rather than snow in northern regions. Widespread increases in heavy precipitation events have been observed, even in places where total amounts have decreased. These changes are associated with increased water vapour in the atmosphere arising from the warming of the world's oceans, especially at lower latitudes. There are also increases in some regions in the occurrences of both droughts and floods IPCC [2].

In recent years, a number of studies have been published focusing on the evolution of precipitation, drought conditions and moisture availability in the Mediterranean during the 20th century (e.g., Pauling and Paeth [3]; LopezMoreno et al. [4]; Sousa et al. [5]).

Trends in precipitation and temperatures in Libya were studied by Zeleňáková et al. [6]. Hydrological time series and rainfall distribution in Slovakia were investigated by Komorník et al. [7], Kohnová et al. [8], Gaál et al. [9], Szolgay et al. [10].

The major possible effects of climate change may include variability in water resources, increase desertification, loss of biodiversity and changes in agricultural productivity (Burlando and Rosso [11]). Precipitation is a good indication of the impacts from climate change on water resources. Changes in precipitation patterns are very important for water resources managers to deal with the water resources planning and management. Variations in precipitation over daily, seasonal, annual, and decadal timescales influence water resource systems (Ampitiyawatta and Shenglian [12]).

This paper presents precipitation trends and using Mann-Kendall nonparametric test in Libya and Slovakia.

\section{Study area}

Libya is situated in North Africa between Egypt and Algeria, with the Mediterranean to the north and Chad and Niger on its southern borders. Apart from the coastal strip and the mountains in the south, it is desert or semi desert. Libya's strategic position in North Africa and its abundant oil and gas resources made it an important trading partner for European states.

Locations of climatic stations in Libya and in Slovakia are listed in Table 1. 
Table 1: $\quad$ List of stations.

\begin{tabular}{|c|c|c|c|}
\hline Stations in Libya & Altitude (m) & Stations in Slovakia & Altitude (m) \\
\hline Nalut & 621 & V. Kapušany & 103 \\
\hline Garyan & 796 & Michalovce & 110 \\
\hline Misurata & 32 & Snina & 235 \\
\hline Sorman & 18 & Lekárovce & 210 \\
\hline Benina & 129 & Tisinec & 216 \\
\hline Derna & 26 & Svidník & 218 \\
\hline Zuwarah & 3 & Bardejov & 305 \\
\hline Al Jaghbub & -1 & Hanušovce & 165 \\
\hline Ghadames & 357 & Moldava n/B & 218 \\
\hline Sabha & 432 & Turňa n/B & 180 \\
\hline Ajdabiya & 7 & Sp. Nová Ves & 456 \\
\hline Homs & 22 & Spišské Vlachy & 380 \\
\hline Syrta & 13 & Kysak & 262 \\
\hline Shahat & 621 & Čaňa & 173 \\
\hline Ghat & 692 & Mníšek n/H & 410 \\
\hline Al Kufrah & 436 & Jakubovany & 410 \\
\hline \multirow[t]{4}{*}{ Jalu } & 60 & Vyšný Čaj & 230 \\
\hline & & Chmelnica & 515 \\
\hline & & V. Kapušany & 103 \\
\hline & & Michalovce & 110 \\
\hline
\end{tabular}

North of Libya is influenced by Mediterranean depressions during winter season as a result of its geographical location, most of the precipitation falls as showers that produced from cumuliform clouds which moved along the coastal line. Some coastal areas and highlands are exposed sometimes for blowing of strong storms accompanied by heavy showers and sudden falling in atmospheric pressure. Rainfall averages ranged in these areas (north of Libya) from about 200 to $500 \mathrm{~mm}$, with a maximum of recording on the regions of Jabal Al Akhdar "the Eastern Highlands" where was about $850 \mathrm{~mm}$, and to about $750 \mathrm{~mm}$ on Jabal Nafusah areas "Western Highlands" (Elfadli [13]). The system of precipitation in Libya is characterized by uneven from side to side, above the average annual rainfall $500 \mathrm{~mm}$ in some mountainous areas in the east, while no more than three 
centimetres in the southern of the country. The size varies of the precipitation from year to year and from season to another within the same year. The climate is Mediterranean along the coast and dry extreme desert is in the interior part of the country.

The territory under this study in Slovakia lies in the eastern part of the country, particularly in the Bodrog and Hornád river basins. The morphological type of terrain in the Hornád valley is dominated by rolling hills, higher and lower uplands. The southern sub-basin is part of a plain and the Slovakian Karst and is formed by moderately higher uplands. The geological structure of the territory determines the hydro-geological conditions of the basin. The sub-basin of the Hornád valley can be assigned to areas with a strong predominance of impervious or poorly permeable rock with moderate to low permeability. Welldrained rock with high permeability exists only in the Spiš and Gemer areas and in the Slovakian Karst near Košice (Zeleňáková [14]).

The Bodrog watershed area, consisting of the Cirocha, Laborec, Latorica, Ondava, Topl'a and Uh river basins, is located in two orographic subassemblies, which are the Carpathian Mountains and the Pannonian Basin. The morphological type of the relief is predominantly flat in the southern part, hilly in the northern part. The Bodrog river valley has varied climatic conditions. Precipitations are highly differentiated. The highest annual totals are mainly in the eastern border mountains and Vihorlat where rainfall totals are about 1000 $\mathrm{mm}$. Decrease in total precipitation is quite marked directly to the south, where annual totals fall to below $800 \mathrm{~mm}$. The Michalovce, Lastomír and Medzibodrožie lowlands rank among the driest in the eastern region (550 mm rainfall per year) (Zeleňáková and Gaňová [15]).

\section{Materials and methods}

Annual and monthly rainfall data at 17 stations in Libya and 20 stations in Slovakia were evaluated in this study. Analysis of the data was carried out for precipitation in the time period 1981-2010. Main data used in the present study were acquired from these Institutes and web sites:

- Libya’s Meteorological Service

- Slovak Hydrometeorological Institute

- National Oceanic and Atmospheric Administration (NOAA) http://www.ncdc.noaa.gov/oa/mpp/digitalfiles.html

- World Weather and Local Weather Forecast http://www.tutiempo.net/en/Climate/Libya/LY.html

In all, a network stations and 30 years of data were set up to study precipitation trend in central and east of Libya and east of Slovakia. This length of data set satisfies the minimum required length in searching for evidence of climate change in hydroclimatic time-series as proposed by Burn and Elnur [16].

In this study non-parametric Mann-Kendall test is used for the detection of the trend in a time series. This test is widely used in the environmental science because it is simple, robust and can cope with missing values and values below a detection limit. The first proposal of the test was by Mann [17] and Kendall [18]. 
Mann-Kendall test is following statistics based on standard normal distribution (Z), by using Eq. (1).

$$
Z=\left\{\begin{array}{ccc}
\frac{S-1}{\sqrt{\operatorname{Var}(S)}} & \text { if } & S>0 \\
0 & \text { if } & S=0 \\
\frac{S+1}{\sqrt{\operatorname{Var}(S)}} & \text { if } & S<0
\end{array}\right.
$$

in which

$$
\begin{gathered}
S=\sum_{k=1}^{n-1} \sum_{k+i}^{n} \operatorname{sgn}\left(x_{j}-x_{k}\right) \\
\operatorname{sgn}\left(x_{j}-x_{k}\right)=\left\{\begin{array}{cc}
+1 & \text { if }\left(x_{j}-x_{k}\right)>0 \\
0 & \text { if }\left(x_{j}-x_{k}\right)=0 \\
-1 & \text { if }\left(x_{j}-x_{k}\right)<0
\end{array}\right. \\
\operatorname{Var}(S)=\left[n(n-1)(2 n+5)-\sum_{i=1}^{m} t_{i}\left(t_{i}-1\right)\left(2 t_{i}+5\right)\right] / 18
\end{gathered}
$$

where

$n$ is the number of data points,

$m$ is the number of tied groups (a set of sample data having the same value).

Hypothesis $\mathrm{HO}$ - no trend is if $\left(Z<Z_{\alpha / 2}\right)$ and $\mathrm{H} 1$ - there is a trend if $Z>Z_{\alpha / 2}$.

Positive values of $Z$ indicate increasing trends, while negative values of $Z$ show decreasing trends. The significance level is chosen as $\alpha=0,05$ and $Z_{\alpha / 2}$ is the value of normal distribution function.

The magnitude of the trend was determined using Sen`s estimator. Sen's method assumes a linear trend in the time series and has been widely used for determining the magnitude of trend in hydro-meteorological time series Sen [19]. In this method, the slopes $(\beta)$ of all data pairs are first calculated by

$$
\beta=\operatorname{Median}\left(\left(x_{j}-x_{k}\right) /(j-k)\right)
$$

for $i=1,2, \ldots, N$, where $x_{\mathrm{j}}$ and $x_{\mathrm{k}}$ are data values at time $j$ and $k(j>k)$, respectively and $N$ is a number of all pairs $x_{\mathrm{j}}$ and $x_{\mathrm{k}}$.

A positive value of $\beta$ indicates an upward (increasing) trend and a negative value indicates a downward (decreasing) trend in the time series.

All mathematical relationships (1-4) and (5) were programmed in Visual Basic in Microsoft Excel 2003.

\section{Results}

The results of precipitation trend analysis are presented for annual (Table 2 and Table 3) and monthly data (Table 4). 
The evaluation was done for the time period from November to October. Data series for the 30 years period was considered for trend detection. In the Sen's method the slope of all the data points are calculated and their median value is the Sen's estimator of slope.

Bold values indicate statistical significance at 95\% confidence level as per the Mann-Kendall test (+ for increasing and - for decreasing).

Table 2: $\quad$ Mann-Kendall statistic and Sen’s estimator for annual precipitation in Libya.

\begin{tabular}{|c|c|c|c|}
\hline Station & $Z$ & $\beta$ & Trend \\
\hline Nalut & 2.47 & -7.1259E-05 & decreasing \\
\hline Garyan & 0.28 & -0 & no \\
\hline Misurata & 0.73 & +0 & no \\
\hline Sorman & 1.52 & -0 & no \\
\hline Benina & 1.97 & $-4.4444 E-05$ & decreasing \\
\hline Derna & 0.15 & -0 & no \\
\hline Zuwarah & 1.66 & -0 & no \\
\hline Al Jaghbub & 1.78 & -0.00027473 & decreasing \\
\hline Ghadames & 1.98 & -0.00020833 & decreasing \\
\hline Sabha & 0.30 & +0 & no \\
\hline Ajdabiya & 0.88 & -0 & no \\
\hline Homs & 2.75 & 0.00031863 & increasing \\
\hline Syrta & 1.27 & +0 & no \\
\hline Shahat & 3.31 & 2.8653E-05 & increasing \\
\hline Ghat & 0.02 & +0 & no \\
\hline Al Kufrah & 1.24 & -0 & no \\
\hline Jalu & 1.50 & +0 & no \\
\hline
\end{tabular}

Trend analysis of annual precipitation shows the negative value in ten stations and the positive value in seven stations. Rainfall data series did not show any clear trend for the Libya's stations. Two stations at the west of the country Nalut and Ghadames and station Benina at the north present clear significant declining trend in rainfall. Two gauging stations presents rising trend in precipitation. Rainfall trends show large variability in magnitude and direction of trend from one station to another. It depends upon many factors, namely latitude, altitude, and distance from the sea. 
Table 3: $\quad$ Mann-Kendall statistic and Sen's estimator for annual precipitation in Slovakia.

\begin{tabular}{|c|c|c|c|}
\hline Station & $Z$ & $\boldsymbol{\beta}$ & Trend \\
\hline V. Kapušany & 1.651504 & 0.024017 & no \\
\hline Michalovce & 0.255527 & 0.004219 & no \\
\hline Snina & 1.517385 & 0.022973 & no \\
\hline Lekárovce & -0.17313 & -0.0027 & no \\
\hline Tisinec & 1.113713 & 0.018135 & no \\
\hline Svidník & 1.221096 & 0.018974 & no \\
\hline Bardejov & 1.986363 & 0.029054 & increasing \\
\hline Hanušovce & 0.883169 & 0.013953 & no \\
\hline Moldava n/B & 0.678046 & 0.01102 & no \\
\hline Turňa n/B & 0.884484 & 0.014198 & no \\
\hline Sp. Nová Ves & 2.361984 & 0.036813 & increasing \\
\hline Spišské Vlachy & 1.838219 & 0.030745 & increasing \\
\hline Kysak & 1.467858 & 0.024306 & no \\
\hline Čaňa & 0.549186 & 0.009486 & no \\
\hline Mníšek n/H & 1.586636 & 0.024651 & no \\
\hline Jakubovany & 2.888379 & 0.057214 & increasing \\
\hline Vyšný Čaj & 2.150725 & 0.041694 & increasing \\
\hline Chmelnica & 1.05279 & 0.016535 & no \\
\hline V. Kapušany & 1.522645 & 0.024409 & no \\
\hline Michalovce & 1.953929 & 0.034146 & increasing \\
\hline
\end{tabular}

Almost all the gauging stations in Slovakia show positive trend of annual precipitation. Bardejov, Sp. Nová Ves, Jakubovany and Vyšný Čaj present clear increasing trend. Three of them are situated in altitude more than $400 \mathrm{~m}$ above sea level. The trend slope is increase of annual precipitation - in Jakubovany it is $0.06 \mathrm{~mm} /$ year.

Regarding trend analysis of monthly precipitation data (Table 4) there is increasing trend in precipitation in the both countries. No trend was proved in the stations situated mostly in the desert. There is no or very small values of rainfall in general. Declining trend was demonstrated in August and November in Libya and in March in Slovakia. Significant positive trend in precipitation was proved in July in Slovakia. 
Table 4: $\quad$ Magnitude of trends for different months

\begin{tabular}{|c|c|c|}
\hline Month & Average trends in Libya & Average trends in Slovakia \\
\hline November & -0.19713 & 0.0742 \\
\hline December & 0.19935 & 0.017508 \\
\hline January & 0.191002 & 0.335072 \\
\hline February & 0.172403 & 0.372848 \\
\hline March & 0.037772 & -0.08085 \\
\hline April & 0.037193 & 0.310805 \\
\hline May & 0.003023 & 0.06184 \\
\hline June & 0 & 0.410784 \\
\hline July & 0 & 1.966329 \\
\hline August & -0.03229 & 0.586126 \\
\hline September & 0.008542 & 0.458285 \\
\hline October & 0.015681 & 0.157809 \\
\hline
\end{tabular}

\section{Conclusions}

The rainfall of a certain place depends upon many factors and some weather conditions. These include latitude, altitude, topography, and distance from the sea, water bodies or other wet areas.

This paper describes the application of a procedure that identifies trends in hydrologic variables - precipitation in Libya and Slovakia. The non-parametric Mann-Kendall statistic test was applied to detect trends and to assess the significance of the trends in the time series. The non parametric Mann-Kendall statistical test has been widely applied to assess the significance of trends in hydrological time series. The site significance of trends in 30 years time series was assessed by the Mann-Kendall test at the significance level of 0.05. In general, precipitation data in study area during the last 30 years has not changed or there are not big gap.

The application of trend detection in Libya has resulted in the identification of more significant trends than are expected to occur by chance. Temporal differences were noted in the occurrence and the direction of trends implying that a systematic framework is essential for detecting trends that might arise as a result of climatic variability. Spatial differences in the trend results can be expected to occur as a result of spatial differences in the changes in precipitation and spatial differences in the country characteristics that translate meteorological inputs into a hydrologic response. Temporal differences in the trends likely reflect non-uniform changes in the meteorological variable. 
The highest risk of drought - decrease of precipitation was proved in the stations Nalut and Ghadames in Libya in the west part of the country. The highest risk of flood - increase of precipitation was proved in the stations Bardejov, Sp. Nová Ves and Jakubovany in Slovakia what prove the real flood situation in the country. Decreasing trend of precipitation was found only in November and August in Libya and in March in Slovakia all other months prove increasing trend of precipitation.

Trend analysis of rainfall data series for 1980-2010 did not show any clear trend for Libya as a whole, although this analysis showed increasing trend in Slovakia. As expected, rainfall trends show large variability in magnitude and direction of trend from one subdivision to another. It is clear that slight climatic changes may have affected the magnitude and timing of the precipitation within the study area.

\section{Acknowledgement}

The Centre was supported by the Slovak Research and Development Agency under the contract No. SUSPP-0007-09.

\section{References}

[1] IPCC Working Group II: Impacts, Adaptation and Vulnerability. Extreme high temperature and precipitation events. http://www.ipcc.ch/ipccreports/ tar/wg2/index.php?idp=625.

[2] Climate Change: Working Group I: The Physical Science Basis. How is Precipitation Changing? 2007. http://www.ipcc.ch/publications_and_data /ar4/wg1/en/faq-3-2.html.

[3] Pauling, A., Paeth, H.: On the variability of return periods of European winter precipitation extremes over the last five centuries. Clim. Past Discuss., 2, 157-189, 2006.

[4] Lopez-Moreno, J., Vicente-Serrano, S., Gimeno, L., Nieto, R.: Stability of the seasonal distribution of precipitation in the Mediterranean region: Observations since 1950 and projections for the 21st century, Geophys. Res. Lett., 36, 10703, doi:10.1029/2009GL037956, 2009.

[5] Sousa, P. M., Trigo, R. M., Aizpurua, P., Nieto, R., Gimeno, L., GarciaHerrera, R.: Trends and extremes of drought indices throughout the 20th century in the Mediterranean. Nat. Hazards Earth Syst. Sci., 11, 33-51, doi:10.5194/nhess-11-33-2011, http://www.nat-hazards-earth-systsci.net/11/33/2011/.

[6] Zeleňáková, M., Purcz, P., Gargar, I.: Trends in precipitation and temperature in Lybia. In: 6th World Aqua Congress: Water Vision 2050, New Delhi: Aqua Foundation, 2012 p. 37-48.

[7] Komorník, J., Komorníková, M., Mesiar, R., Szökeova, D., Szolgay, J.: Comparison of forecasting performance of nonlinear models of hydrological time series. Physics and Chemistry of the Earth 31 (2006) $1127-1145$. 
[8] Kohnová, S., Lapin, M., Szolgay, J., Gaál, L.: Methodology for the selection of 10-day maximum precipitation totals and their statistical analysis in the upper Hron region. Contributions to Geophysics and Geodesy, Vol. 35/3, 2005.

[9] Gaál, L., Kyselý, J., Szolgay, J.: Region-of-influence approach to a frequency analysis of heavy precipitation in Slovakia. Hydrol. Earth Syst. Sci., 12, 825-839, 2008.

[10] Szolgay, J., Parajka, J., Kohnová, S., Hlavčová, K.: Comparison of mapping approaches of design annual maximum daily precipitation. Atmospheric Research, Vol. 92, Issue 3, 2009, p. 289-307.

[11] Burlando, P. and R. Rosso (2002). Effects of transient climate change on basin hydrology. 1. Precipitation scenarios for the Arno River, central Italy. Hydrological Processes, 16(6): pp 1151-1175.

[12] Ampitiyawatta, A.D., Shenglian, G.: Precipitation trends in the Kalu Ganga basin in Sri Lanka. The Journal of Agricultural Science, vol.4, no.1, 2009

[13] Elfadli, K. I.: Precipitation data of Libya. Libyan National Meteorological Center, 2009.

[14] Zeleňáková, M.: Preliminary flood risk assessment in the Hornád watershed. In: River Basin Management 5. Southampton: Wessex Institute of Technology, p. 15-24, 2009.

[15] Zeleňáková, M., Gaňová L.: Integrating multicriteria analysis with geographical information system for evaluation flood vulnerable areas. In: SGEM 2011: 11th International Multidisciplinary Scientific GeoConference: Sofia: STEF92 Technology, p. 433-440, 2011.

[16] Burn, D.H., Hag Elnur, M.A.: Detection of hydrologic trends and variability. Journal of Hydrology 255,107-122, 2002.

[17] Mann, H.B.: Non-parametric tests against trend. Econometrica 13, 245-259, 1945.

[18] Kendall, M.G.: Rank Correlation Measures. Charles Griffin, London. 1975.

[19] Sen, P. K.: Estimates of the regression coefficient based on Kendall's tau. Journal of the American Statistical Association 63: 1379-1389, 1968. 